М.В. Касаткін

Харківський національний університет Повітряних Сил ім. І. Кожедуба, Харків

\title{
СТОХАСТИЧНЕ МОДЕЛЮВАННЯ СУМІСНОГО ПРИЙНЯТТЯ РІШЕНЬ “ЕКІПАЖ - КЕРІВНИК ПОЛЬОТІВ” В ОСОБЛИВОМУ ВИПАДКУ В ПОЛЬОТІ
}

У статті представлено моделі сумісного прийняття рішень (СDМ) екіпажем повітряного судна та керівником польотів в умовах стохастичної невизначеності у вигляді дерева рімень та мережі GERT. Наведено приклад CDM в особливому випадку “Відмова лівого двигуна (відмова системи граничного обмеження температури) двомоторного літака”. Для комплексного обліку факторів, які впливають на процес CDM в особливих випадках в польоті, побудовано інтелектуальну систему підтримки СDМ, щзо дозволяє враховувати динамічну, статичну та експертну інформацію щзодо стану об'єкту управління (повітряного судна), зовнішнього середовища (характеристики зони управління повітряним рухом та аеродромів) та операторів аеронавігаційної системи (характеристики пілота, авіадиспетчера).

Ключові слова: дерево рішень, інтелектуальна система підтримки сумісного прийняття рішень, мережа GERT, польотна ситуація, порушення взаємодї, сценарій розвитку.

\section{Вступ}

Постановка проблеми. Будь-якій людині властиві обмеження можливостей або помилки. Не завжди психологічні та психофізіологічні характеристики людини відповідають рівню складності завдань або проблем, що виникають. Помилки, які називають проявом людського фактору, як правило, ненавмисні: людина виконує помилкові дії, розцінюючи їх як вірні або найбільш підходящі. Людський фактор діє тільки в сукупності з іншими, наприклад, технічними та погодними факторами.

Причини, що сприяють помилковим діям людини, можна об'єднати в кілька груп [1]:

- недоліки інформаційного забезпечення, відсутність обліку людського фактору;

- обмеженість ресурсів підтримки і виконання прийнятого рішення.

- помилки, які викликані зовнішніми факторами;

- помилки, які викликані фізичним і психологічним станом і властивостями людини.

Причиною появи помилок людини можуть бути відсутня або недостатня інформаційна підтримка (спеціальні обробники таких ситуацій в програмному забезпеченні, наочні матеріали та інструкції); особливо сильно ця проблема проявляється в екстремальних ситуаціях і в умовах дефіциту часу на прийняття рішення.

Відсутність повної впевненості в успішності виконання майбутньої дії, сумніви в можливості досягнення мети діяльності породжують емоційну напруженість, яка проявляється як надмірне хвилювання, інтенсивне переживання людиною процесу діяльності і очікуваних результатів. Емоційна на- пруженість веде до погіршення організації діяльності, надмірного збудження або загальної загальмованості та скутості в поведінці, зростанні ймовірності помилкових дій [2].

Безпека польоту багато в чому досягається завдяки правильним діям екіпажу. Наприклад, всього лише при ускладненні умов польоту результатом прийнятого екіпажем помилкового рішення і його подальших неправильних дій стала катастрофа. В іншому випадку (успішний результат), при виникненні практично катастрофічної ситуації і в умовах дефіциту часу командир екіпажу зумів забезпечити безпеку і не допустити людських жертв.

Виникнення небезпечної (особливої) ситуації в польоті може бути наслідком безлічі різних причин. Людський фактор може зіграти свою роль на будьякому етапі виконання польоту, тому як катастрофа відбувається при додаванні (або накладенні) двох і більше несприятливих для польоту повітряних суден (ПС) подій. Льотна експлуатація ПС - це комплекс дій персоналу багатьох служб і під терміном “людський фактор” (ЛФ) не можна вузько розуміти тільки дії льотного екіпажу [2-4].

На конференції Генеральних директорів цивільної авіації з глобальної стратегії в сфері безпеки польотів, що проходила в Монреалі в 2006 р. [5], було відзначено, що внаслідок досягнутого прогресу в конструкції ПС і підвищення надійності авіатехніки, частка авіаційних подій через іiї відмову і через неоптимальність ii технічних характеристик зменшилася до величини порядку 15\%, а частка подій, що виникли внаслідок відхилень у роботі персоналу, в основному льотного екіпажу, зросла до $80 \%$ від загальної їх кількості. А за даними Міжнародного авіаційного комітету [1], в 2019 р. близько 85\% авіа- 
ційних подій в цивільній авіації держав СНД - учасниць Угоди було обумовлено цією причиною. Іншими словами, “помилка пілота” стала основним фактором виникнення небезпеки в польоті.

Будь-який інцидент є квінтесенцією помилок. При проведенні розслідування авіаційної події виявляються ті помилки, які були допущені на різних етапах: підготовка пілота, обслуговування літака, недоліки в аеронавігаційному обслуговуванні та інші моменти [6].

Аналіз останніх досліджень і публікацій. За статистикою ASN за 2018 рік, лише один з 2,52 млн. польотів закінчився інцидентом 3 людськими жертвами. У 2017 році цей показник був краще: одна катастрофа на 7,36 млн. польотів. Проте, як заявляють в організації, ситуація в сфері авіаційної безпеки за останній час значно покращилася [7].

Фахівцям 3 дослідження авіаційних подій визначено основні причини аварій і їх вірогідність на різних етапах польоту [7-8]:

- помилки екіпажу при посадці - 51\%;

- несправності й погодні умови при наборі висоти - $8 \%$;

- при зниженні - 3\%;

- під час завантаження - 5\%;

- під час заходу на посадку - 7\%.

На сьогоднішній день ключову роль в забезпеченні безпеки польотів грає проблема організації сумісного прийняття рішень (CDM - Collaborative Decision Making) усіма операційними партнерами аеропортом, службою управління повітряним рухом, авіакомпаніями та наземними операторами - на основі спільної інформації про процес польоту та наземне обслуговування повітряного судна в аеропорту [9]. Глобальною експлуатаційною концепцією організації повітряного руху [10] передбачається забезпечення спільного (пілот-авіадиспетчер) прийняття рішень 3 управління повітряним рухом на основі діалогу між ними та оцінки інформації в реальному масштабі часу на всіх етапах польоту. Саме від адекватної взаємодії між пілотом і авіадиспетчером залежить життя авіапасажирів в небі і третіх осіб на землі.

Взаємодію можна розглядати як процес впливу суб'єктів один на одного, який характеризується виникненням зв'язків, взаємозумовленістю і опосередкованістю їх спільної діяльності або спілкування [11]. Взаємодія сприяє взаємному регулюванню, взаємовпливу, взаємному контролю, взаємодопомозі. Все це передбачає, що кожен з учасників взаємодії зробить свій внесок у виконання спільного завдання, коректуючи свої дії, враховуючи попередній досвід, активізуючи власні здібності й можливості партнера. Тобто, спілкуючись, обмінюючись інформацією, людина виробляє форми й норми спільних дій, організовує й координує ці дії.
Особливу значущість узгодженість дій екіпажу та диспетчера набуває в ситуаціях, які виникають в польоті внаслідок впливу небезпечних факторів особливих випадках в польоті (ОВП) [12], основними характеристиками яких є гострий дефіцит часу на прийняття рішень, неповнота і невизначеність наявної інформації, а також значне психофізіологічне навантаження на екіпаж ПС.

В ОВП особливе значення має забезпечення стислості, точності і процедурної сумісності інформаційної взаємодії пілота та авіадиспетчера.

Процес взаємодії класично розглядається як такий, що включає в себе три складові [11]:

- комунікативну (лат. communico - пов'язую, спілкуюся) сторону спілкування, що представляє собою активний обмін інформацією між тим, хто іiі повідомляє (комунікатором) і тим, хто іiі сприймає (реципієнтом);

- соціально-перцептивну (лат. socialis - громадський + perception - сприйняття) сторону спілкування, що представляє собою процес сприйняття партнерами по спілкуванню один одного і встановлення на цій основі взаєморозуміння;

- інтерактивну (лат. inter - між + activus - діяльний) сторону спілкування, що включає в себе різні феномени взаємодії.

CDM відноситься до категорії групових (колективних) рішень і представляє собою здійснюваний групою вибір з ряду альтернатив в умовах взаємного обміну інформацією при вирішенні загальної для всіх членів групи завдання [13].

У середині 1980-х років у соціології при вивченні процесу сумісного (спільного) прийняття рішень (ПР) з'явився термін “колективний розум” або “колективний інтелект" (Collective Intelligence), який визначається як здатність групи знаходити більш ефективні рішення задач, ніж найкраще індивідуальне рішення у цій групі [14]. У загальному випадку CDM має наступні переваги перед одноосібним (індивідуальним) ПР [13]:

1. Потенційна можливість прийняття більш вірних рішень за рахунок їх більшої обгрунтованості.

2. Більш висока ступінь прагматичності рішень за рахунок вибору кращих альтернатив та усунення слабких.

3. Розгляд рішення з точок зору різних фахівців.

4. Значно більш висока стійкість від впливу зовнішніх факторів, менший рівень ризиків.

5. Менша залежність від особливостей конкретної особистості.

6. Використання знань і досвіду кожної особи.

$\mathrm{CDM}$ визначає узгоджений порядок прийняття рішення двома і декількома суб'єктами аеронавігаційної системи (АНС). В рамках даного процесу суб'єкти АНС обмінюються інформацією, що стосу- 
ється цього рішення, домовляються про підхід i принципи прийняття рішень і застосовують їх на практиці. Основне завдання даного процесу - підвищити ефективність АНС в цілому, дотримуючись при цьому рівності інтересів окремих учасників аеронавігаційного обслуговування [9-10; 15-17].

Метою статті $\epsilon$ моделювання сумісного ПР екіпажем літака та керівником польотів при виникненні ОВП в умовах стохастичної невизначеності у вигляді дерева рішень та мережі GERT, розробка концептуальної моделі інтелектуальної системи підтримки спільного прийняття рішення (ІСПСПР) для комплексного обліку факторів, які впливають на процес CDM операторами АНC в ОВП.

\section{Виклад основного матеріалу}

\section{Моделювання сумісного прийняття рішень операторами АНС в умовах стохастичної невизначеності}

Будь-який інцидент є квінтесенцією помилок. При проведенні розслідування авіаційної події виявляються ті помилки, які були допущені на різних етапах: підготовка пілота, обслуговування літака, недоліки в аеронавігаційному обслуговуванні та інші моменти [6].

Недостатня підготовка командира екіпажу з техніки пілотування, членів екіпажу по діям в позаштатних ситуаціях, відмова систем літака, мала висота польоту та невтручання наземної служби управління польотами можуть бути причинами розвитку польотної ситуації від складної до аварійної, а згодом і до катастрофічної.

Пропонується розглянути чотири можливі сценарії розвитку подій, за якими можливо уникнути катастрофи.

1. Борттехнік під час розбігу вчасно виявляє відмову системи граничного обмеження температури лівого двигуна і доповідає за встановленою формою командиру повітряного судна (КПС). КПС приймає рішення до швидкості ПР $\mathrm{V}_{1}$ про припинення зльоту. КПС подає команду “Зліт припинити. РУД нуль” та, витримуючи напрямок руху, починає гальмування педалями. Враховуючи довжину злітно-посадкової смуги (ЗПС) аеродрому, швидкість літака та довжину пробігу літака, то найбільш ймовірне викочування за межі ЗПС та пошкодження шасі. В цьому випадку КПС доповідає керівнику польотів (КрП) про припинення зльоту, місце зупинки та пошкодження літака і запрошує у КрП допомогу аварійної служби.

2. Під час виконання посадки та зльоту “конвеєром” борттехнік переставляє закрилки з посадкового положення у злітне положення та переводить важелі управління двигунами РУД у положення, що відповідає злітному режиму їх роботи. Під час збільшення режиму роботи двигунів виникає відмова системи граничного обмеження температури. Таким чином параметри роботи лівого двигуна мають відхилення від норми. Через швидкоплинність зльоту “конвеєром” від моменту переведення РУД до досягнення швидкості ПР $V_{1}$ борттехнік не помічає загорання червоної сигнальної лампи, що вказує на відмову лівого двигуна. Борттехнік доповідає КПС про відхилення роботи лівого двигуна, але КПС приймає рішення про виконання зльоту. Після зльоту та прибирання шасі, закрилків КПС доповідає КрП про відмову лівого двигуна та запитує дозвіл на виконання заходу зі зворотнім курсом. КрП дає дозвіл на захід зворотнім курсом та дає рекомендації по діям при відмові двигуна. КрП інформує диспетчерів про виконання аварійним літаком заходу зі зворотнім курсом, дає розпорядження інженеру з радіотехнічних засобів (РТЗ) на перемикання усіх РТЗ на зворотній курс, запитує погодні умови зі зворотнім курсом у метеорологічної служби. КрП передає інформацію від інженера з РТЗ та метеослужби екіпажу ПС. Після отримання дозволу та рекомендацій, екіпаж вимикає лівий двигун та виконує захід на посадку зі зворотнім курсом, борттехнік за командою КПС випускає шасі, закрилки на $15^{\circ}$ в декілька прийомів. Екіпаж виконує посадку, КПС доповідає КрП про посадку та запрошує у КрП допомогу аварійної служби.

3. Після зльоту та прибирання закрилків, виявлення відмови системи граничного обмеження температури, КПС приймає рішення про виконання польоту по колу. На траверзі ДПРМ борттехнік доповідає про подальше падіння потужності лівого двигуна. КПС доповідає КрП про падіння потужності лівого двигуна та запрошує пріоритет для виконання посадки. КрП залучає фахівців інженерноавіаційної служби для надання допомоги екіпажу та дає рекомендації по діям при відмові двигуна. КПС дає команду борттехніку вимкнути лівий двигун та запустити ВСУ. Борттехнік вимикає лівий двигун та запускає ВСУ. Після виконання четвертого розвороту борттехнік випускає шасі та випускає закрилки на $15^{\circ}$ в декілька прийомів. КПС виконує балансування літака тримерами та виконує посадку. На пробігу утримує літак від розвертання. Після зупинки КПС доповідає КрП та запрошує у КрП допомогу аварійної служби.

4. Після зльоту та прибирання закрилків, виявлення відмови системи граничного обмеження температури, КПС приймає рішення про виконання польоту по колу. На траверзі ДПРМ борттехнік доповідає про подальше падіння потужності лівого двигуна. КПС доповідає КрП про падіння потужності лівого двигуна та запрошує пріоритет для виконання посадки. Незважаючи на ознаки відмови, КПС не дає команду вимикати лівий двигун. Борттехнік за командою КПС запускає ВСУ. Після вико- 
нання четвертого розвороту КПС дає команду випустити шасі, закрилки на $15^{\circ}$. Над ДПРМ борттехнік за командою КПС випускає закрилки в посадочне положення та при зменшені шляхової швидкості збільшує режим роботи двигунів 3 метою підтримання заданої швидкості передпосадкового зниження. При цьому потужність лівого двигуна залишається на рівні малого газу. Борттехнік доповідає КПС про відмову лівого двигуна, за командою КПС кнопкою флюгирує лівий двигун та прибирає закрилки на $15^{\circ}$. Під час виконання вказаних процедур швидкість літака знижується до швидкості звалювання, на такій швидкості керування має низьку ефективність. Задля покращення керованості КПС збільшує швидкість зниження, віддавши штурвал від себе. Витримувати курс посадки за таких умов неможливо, за наявної висоти та швидкості неможливо виконати посадку на ЗПС. Найбільш ймовірно, що приземлення буде лівіше від БПРМ. Посадка поза ЗПС з підвищеною вертикальною швидкістю може призвести до руйнування шасі, конструкції літака, виникнення пожежі. Після зупинки КПС доповідає КрП про місце аварійної посадки, КрП приймає заходи з організації пошуку та рятування ПС i людей.

Для дослідження закономірностей взаємодії “екіпаж - керівник польотів” розроблені стохастичні моделі ПР і розвитку польотної ситуації. Для формалізації поведінки “екіпаж - керівник польотів” в польотній ситуації зручними є моделі, що представляють процес появи окремих передумов і розвитку їх у причинний ланцюг подій у вигляді відповідних діаграм.

Найбільше поширення одержали діаграми у формі різних графів (або потокових станів і переходів), а також функціональних мереж стохастичної структури [3]. Існують декілька різновидів діаграм впливу типу дерево: дерево наслідків; дерево подій; дерево розвитку ситуацій; дерево рішень тощо.

На рис. 1 наведено приклад дерева рішень при виникненні ОВП .

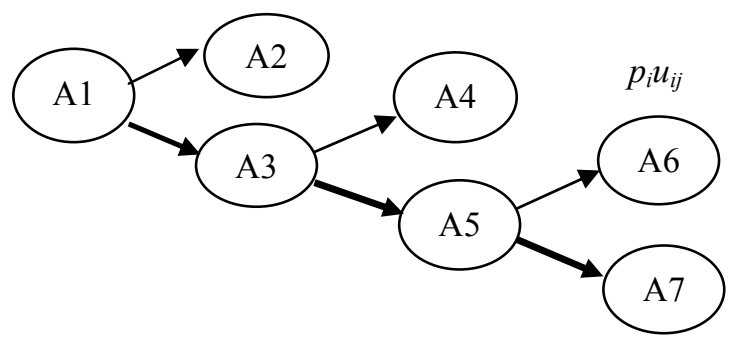

Рис. 1. Дерево рішень при виникненні ОВП

"Відмова лівого двигуна (відмова системи граничного обмеження температури) двомоторного літака"

Джерело: розроблено автором.

Де, на рис. 1: А1 - відмова лівого двигуна; А2 припинення зльоту; А3 - виконання зльоту; А4 - виконання заходу зі зворотнім курсом; А5 - виконання польоту “по коробочці"; А6 - вимикання лівого двигуна на траверзі та захід на посадку на одному двигуні; А7 - захід на двох двигунах, випуск закрилків на $38^{\circ}$, відмова лівого двигуна, вмикання флюгера лівого двигуна, прибирання закрилків на $15^{\circ}$, посадка до ЗПС; $p_{i}$ - ймовірності впливу несприятливих факторів; $u_{i j}$ - збиток при виборі певної альтернативи ПР

Для моделювання розвитку ОВП використовуються моделі у вигляді стохастичної мережі типу GERT (Graphical Evaluation and Review Technique “Метод графічної оцінки й аналізу”).

GERT $є$ альтернативним імовірнісним методом мережевого планування, що застосовується у випадках організації діяльності, коли наступні дії можуть починатися після завершення тільки деякого числа 3 попередніх дій, тому допускає наявність циклів і петель [3]. На рис. 2 представлений приклад стохастичної мережі розвитку польотної ситуації типу GERT при виникненні ОВП.

За допомогою мережі GERT визначаються [3]: математичне очікування часу $t_{i j}$ розвитку ситуації, дисперсія часу $t_{i j}$ розвитку ситуації, перехідні ймовірності розвитку польотної ситуації $p_{i j}$, ймовірності виникнення станів польотних ситуацій $p\left(G_{i}\right)$ (нормальної $p(G 1)$, ускладненої $p(G 2)$, складної $p(G 3)$, аварійної $p(G 4)$, катастрофічної $p(G 5))$.

Позитивний (негативний) розвиток польотної ситуації залежить як від дії зовнішнього середовища (складні метеорологічні умови тощо), так і від CDM “екіпаж - керівник польотів”, які мають характерні особистісні якості.

Врахування впливу на прийняття рішення операторами АНС факторів професійного та непрофесійного характеру, дозволяє прогнозувати їх дії в позаштатних ситуаціях, моделювати можливий розвиток ситуації в польоті [14; 16].

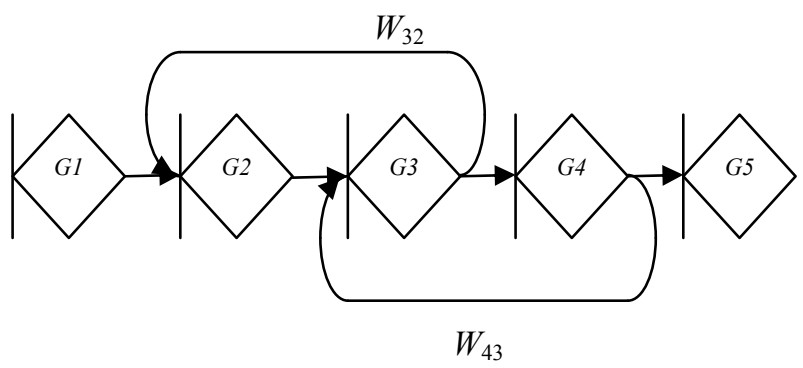

Pис. 2. Мережа GERT

Джерело: розроблено автором.

Де: $W_{32}$ - дуга переходу з складної ситуації в ускладнену, коли екіпаж вимикає лівий двигун на 
траверзі та заходить на посадку на одному двигуні; $\mathrm{W}_{43}$ - дуга переходу з аварійної ситуації в складну, коли екіпаж заходить на двох двигунах, випускає закрилки на $38^{\circ}$, виникає відмова лівого двигуна, екіпаж флюгирує лівий двигун, прибирає закрилки на $15^{\circ}$, виконує посадку до ЗПС.

Один 3 документів, який відповідно до Авіаційних правил України повинен бути на борту ПС, $\epsilon$ Quick Reference Handbook - збірник дій екіпажу в особливих випадках в польоті, в якому вказані усі можливі ОВП, ознаки цих випадків та порядок дій у вигляді контрольних карт (Emergency Check List) для усіх членів екіпажу при виникненні таких випадків. При виявленні відмови, виникненні ОВП, КПС доповідає КрП та дає команду читати контрольну карту, що запобігає неповному виконанню рекомендацій КЛЕ членами екіпажу по діям при відмові. Задля CDM КрП дає рекомендації екіпажу по діям для парирування ОВП.

\section{Концепція інтелектуальної системи підтримки сумісного прийняття рішень операторів АНС в ОВП}

Одним 3 підходів до підвищення ефективності ПР операторами, особливо в екстремальних ситуаціях, є застосування інтелектуальних систем підтримки прийняття рішень (ICППР) (IDSS - Intelligent Decision Support Systems) [18-21]. Загалом ІСППР можна визначити як інтерактивну комп'ютерну систему, призначену для підтримки різних видів діяльності фахівця під час ПР щодо слабоструктурованих і неструктурованих проблем, яка грунтується на використанні моделей та процедур 3 обробки даних i знань на основі технологій штучного інтелекту.

Як показали дослідження, CDM пілотом/авіадиспетчером в ОВП вимагає від операторів аналізу значних обсягів різнопланової інформації. Для комплексного обліку факторів, які впливають на процес CDM в ОВП, побудовано адаптивну інтелектуальну систему підтримки сумісного прийняття рішень (ІСПСПР), що дозволяє враховувати динамічну, статичну та експертну інформацію щодо стану об'єкту управління (ПС), зовнішнього середовища (характеристики зони управління повітряним рухом (УПР) та аеродромів) та операторів АНC (характеристики пілота, авіадиспетчера).

Основними задачами ІСПСПР пілотом/авіадиспетчером в ОВП є:

1. Збір даних щодо стану об'єкта управління (ПС), зовнішнього середовища (зони УПР) та операторів АНС (пілота, авіадиспетчера).

2. Прогнозування розвитку польотної ситуації на борту.

3. Формування множини альтернативних дій в даній польотній ситуації (наприклад, продовження польоту до аеродрому призначення (запасного) або виконання вимушеної посадки).

4. Оцінка ефективності можливих альтернатив та формування рекомендацій з визначення оптимального варіанта дій.

Задачі ІСПСПР пов'язані з необхідними даними, які можна розділити на три категорії: статичні, динамічні (оперативні) та експертні.

До статичних даних щодо ПС відносяться тактико-технічні характеристики ПС:

- кількість, тип та розташування двигунів;

- горизонтальні й вертикальні швидкості за етапами та висотами польоту;

- максимальний кут крену;

- аеродинамічна якість;

- нормативна посадкова маса ПС;

- мінімум ПС для посадки;

- допустимий стан ЗПС;

- необхідна для посадки довжина ЗПС в стандартних умовах;

- допустимі складові вітру для посадки;

та планові, які система отримує з попередньо оформленого й поданого до служби руху плану польоту ПС:

- тип ПС та мінімум КПС для посадки.

Динамічна інформація щодо ПС включає моніторингові дані, які отримують в процесі безпосереднього спостереження за ПС:

- тип польотної ситуації, стан та висота ПС;

- координати та курс польоту ПС;

- фактична посадкова маса ПС.

До статичної інформації щодо зони УПР та аеродромів відносяться наступні дані:

- схема повітряних трас та розташування навігаційних засобів;

- межі прийому-передачі УПР;

- координати аеродромів;

- висоти та мінімуми аеродромів;

- схеми заходу на посадку на аеродромах;

- кількість і тип ЗПС на аеродромах (штучна або грунтова);

- довжина, посадочний кут та нахил ЗПС.

До динамічної інформації щодо зони УПР та аеродромів відносяться:

- повітряна обстановка та заборони та обмеження використання повітряного простору;

- стан ЗПС (наявність ремонтних робіт, час звільнення ЗПС, коефіцієнт зчеплення, наявність снігу, сльоти, води, льоду, вологість і міцність грунту, міцність снігу);

- стан РТЗ посадки (працездатність або непрацездатність);

- метеорологічні умови на маршруті та на аеродромах (небезпечні явища погоди, хмарність i видимість, напрямок і сила вітру, фактична температура). 
До статичної інформації щодо операторів АНС (пілота, авіадиспетчера) відносяться наступні дані:

- рівень освіти та стаж роботи за фахом;

- клас фахівця, який визначається знаннями, навичками та вміннями, отриманими протягом навчання та професійної діяльності;

- досвід дій в ОВП;

- індивідуально-психологічні характеристики (темперамент, увага, сприйняття, мислення, уява, натура, воля, здоров'я, досвід, пам'ять);

- психофізіологічні характеристики (часова затримка реакціі, нервово-м'язове запізнювання, час на ПР, емоційний тип, соціотип);
- соціально-психологічні характеристики (система переваг під впливом соціальних, економічних, правових, політичних, моральних факторів).

До динамічної інформації щодо операторів АНС (пілота, авіадиспетчера) відносяться:

- склад екіпажу ПС;

- склад диспетчерської зміни.

Розроблено концептуальну модель ІСППСР пілотом/авіадиспетчером в ОВП, яка використовує моделі CDM на базі штучної нейронної мережі (рис. 3) [22-23].

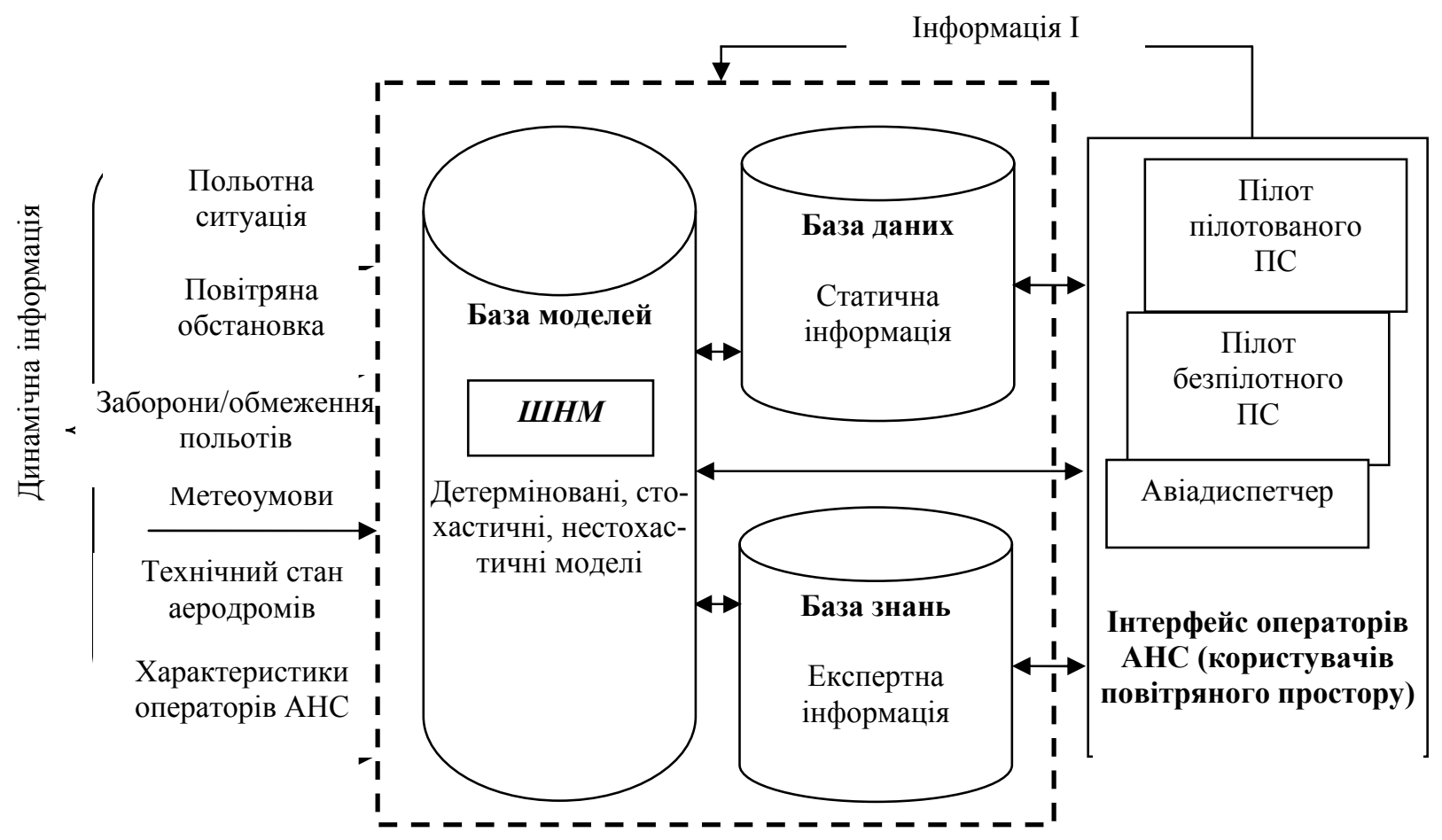

Рис. 3. Концептуальна модель ІСПСПР пілотом/авіадиспетчером в ОВП Джерело: розроблено автором.

Аналіз рис. 3 дозволяє зробити висновки про необхідність створення баз даних (БД) двох видів. До першої групи віднесемо бази, які представляють собою стаціонарне джерело даних - вони створюються до початку роботи ІСПСПР; до другої - динамічне джерело даних - БД, які будуються самою системою при обробці динамічної інформації щодо ПС, зони УПР, операторів АНС та надалі нею використовуються.

Виходячи з цього, визначимо, які саме БД складуть основу обох груп.

До першої увійдуть наступні БД:

- тактико-технічні характеристики ПС;

- планова інформація щодо ПС;

- характеристика зони УПР.

Основу другої групи складуть:

- моніторингові дані щодо ПС;
- технічна інформація щодо аеродромів;

- метеорологічна інформація щодо зони УПР.

При створенні названих БД особливо важливо дотримуватись принципу розвитку, що викликано специфікою об'єкта управління і зовнішніх умов ïx динамікою. Це повинно позначитись і на виборі програмної платформи будування, і на розробці структури БД.

При побудові ІСППСР необхідною є реалізація основних концепцій інформаційних систем, таких як інтерактивність, потужність, доступність, гнучкість, надійність, робастність і керованість [24-25].

В базі знань міститься експертна інформація, отримана шляхом експертного опитування авіаційних фахівців (значення параметрів моделей $\mathrm{CDM}$ ), та правила користування цими даними.

На основі інформації, отриманої від операторів 
АНС (користувачів повітряного простору), можливе коректування баз моделей, даних та знань.

\section{Висновки}

Розроблено стохастичні моделі сумісного ПР екіпажем літака та керівником польотів при виникненні ОВП “Відмова лівого двигуна (відмова системи граничного обмеження температури) двухмоторного літака" у вигляді дерева рішень та мережі GERT.

Дослідження показали, що CDM пілотом/авіа- диспетчером в ОВП вимагає від операторів аналізу значних обсягів різнопланової інформації. Для комплексного обліку факторів, які впливають на процес СDM в ОВП, побудовано адаптивну ІСПСПР, що дозволяє враховувати динамічну, статичну та експертну інформацію щодо стану об'єкту управління (ПС), зовнішнього середовища (характеристики зони УПР та аеродромів) та операторів АНC (характеристики пілота, авіадиспетчера).

\section{Список літератури}

1. Состояние безопасности полетов в гражданской авиации государств-участников Соглашения о гражданской авиации и об использовании воздушного пространства в 2018 г. [Электронный ресурс] - М.: МАК, 2019. - 107 с. - Режим доступа: http://surl.li/iakg.

2. Лейченко С.Д. Человеческий фактор в авиации: монография в 2-х кн. Кн. 1 / С.Д. Лейченко, А.В. Малишевский, Н.Ф. Михайлик. - Кировоград: КОД, 2006. - 480 с.

3. Харченко В.П. Прийняття рішень в соціотехнічних системах: монографія / В.П. Харченко, Т.Ф. Шмельова, Ю.В. Сікірда. - К.: Національний авіаційний університет, 2016. - 308 с.

4. Быковцев И.С. Человеческий фактор в системе организации воздушного движения / И.С. Быковцев, В.М. Гладков. - К.: ГП ОВД, 2009. - $440 \mathrm{c.}$

5. Directors General of Civil Aviation Conference on Global Strategy for Aviation Safety [Electronic resource]. Montreal, 20 to 22 March 2006. - 60 p. - Available at: http://surl.li/iakj.

6. Аптуков Р.Л. Проще обвинить экипаж. Особенно если экипаж погиб [Электронный ресурс] / Р.Л. Аптуков. - Режим доступа: https://www.gazeta.ru/business/2016/04/08/8167415.shtml.

7. Aviation Safety Network. Aviation Safety Network releases 2018 airliner accident statistics [Electronic resource]. Available at: https://news.aviation-safety.net/2019/01/01/aviation-safety-network-releases-2018-airliner-accident-statistics/.

8. Aviation Safety Network. ASN data show 2017 was safest year in aviation history [Electronic resource]. - Available at: https://news.aviation-safety.net/2017/12/30/preliminary-asn-data-show-2017-safest-year-aviation-history/.

9. Manual on Collaborative Decision-Making [Electronic resource]. - Montreal: ICAO, 2014. - 166 p. - Available at: http://surl.li/iakr.

10. Global Air Traffic Management Operational Concept [Electronic resource]. - Montreal: ICAO, 2005. - 82 p. - Available at: http://surl.li/iaku.

11. Карпенко Л.А. Краткий психологический словарь / Л.А. Карпенко, А.В. Петровский, М. Г. Ярошевский. - 2-е изд. - Ростов-на-Дону: ФЕНИКС, 1998. - 512 с.

12. Наказ Міністерства оборони України "Про затвердження правил польотів державної авіації в повітряному просторі України № 700 від 09.12.2015” [Електронний ресурс]. - Режим доступу: http://surl.li/iakz.

13. Жуковська О.А. Математичні моделі колективних рішень: монографія / О.А. Жуковська, Л.С. Файнзільберг. К.: Освіта України, 2018. - 160 с.

14. New Jersey Institute of Technology [Electronic resource]. - Available at: https://www.njit.edu/.

15. Manual on Flight and Flow Information for a Collaborative Environment [Electronic resource]. - Montreal: ICAO, 2012. - 140 p. - Available at: http://surl.li/ialm.

16. Global Air Navigation Plan 2016-2030 [Electronic resource]. - Montreal: ICAO, 2016. - 142 p. - Available at: http://surl.li/ialp.

17. The Manual Airport CDM Implementation. - Brussels: European Organization for the Safety of Air Navigation, 2012. $-359 \mathrm{p}$.

18. Інтелектуальні системи підтримки прийняття рішень: Теорія, синтез, ефективність / В.О. Тарасов, Б.М. Герасимов, І.О. Левін, В.О. Корнійчук. - К.: МАКНС, 2007. - 336 с.

19. Глухих И.Н. Интегрированные автоматизированные системы интеллектуальной поддержки принятия решений при управлении воздушным движением (теория, модели, алгоритмы, принятие решений): автореф. дис. ... доктора техн. наук: 05.13.16 / И.Н. Глухих. - Самара, 2000. - 34 с.

20. Петров К.К. Интеллектуальная навигационная тренажерно-обучающая система: дис. ... канд. техн. наук: 05.13.01 / К.К. Петров. - СПб., 2006. - 176 с.

21. Теоретичні основи автоматизації процесів вироблення рішень в системах управління Повітряних Сил: монографія / О.В. Александров, Д.Е. Двухглавов, М.А. Павленко, О.І. Тимочко.- Х.: ХУПС, 2009. - 176 с.

22. Модель нечіткого виводу адаптивної повітряної обстановки до рівня підготовки диспетчера управління повітряним рухом / К.Ю. Сурков, В.В. Калачова, А.С. Луценко, М.В. Касаткін // Системи озброєння і військова техніка. 2019. - № 1 (57). - C. 34-41. https://doi.org/10.30748/soivt.2019.57.05.

23. Sikirda Yu. Intelligent Automated System for Supporting the Collaborative Decision Making by Operators of the Air Navigation System during Flight Emergencies / Yu. Sikirda, M. Kasatkin, D. Tkachenko // Handbook of Research on Artificial 
Intelligence Applications in the Aviation and Aerospace Industries. - Hershey: IGI Global, 2020. - 66 p. https://doi.org/10.4018/978-1-7998-1415-3.ch003.

24. ДСТУ 2227-93. Системи оброблення інформації. Автоматизована установа. Терміни та визначення. - К., 1993. $-27 \mathrm{c}$.

25. ДСТУ 2941-94. Системи оброблення інформації. Розроблення систем. Терміни та визначення. - К., $1995 .-20$ с.

Надійшла до редколегії 06.10.2020

Схвалена до друку 01.12.2020

\section{Відомості про автора:}

Касаткін Микола Володимирович начальник обслуги обслуговування військової частини А4104

Харківського національного університету

Повітряних Сил ім. І. Кожедуба,

Чугуїв, Україна

https://orcid.org/0000-0002-2501-1756
Information about the author:

\author{
Mykola Kasatkin \\ Chief of Service \\ of Military Unit A4104 \\ of Ivan Kozhedub Kharkiv National \\ Air Force University, \\ Chuguiv, Ukraine \\ https://orcid.org/0000-0002-2501-1756
}

\title{
СТОХАСТИЧЕСКОЕ МОДЕЛИРОВАНИЕ СОВМЕСТНОГО ПРИНЯТИЯ РЕШЕНИЙ “ЭКИПАЖ - РУКОВОДИТЕЛЬ ПОЛЕТОВ” В ОСОБОМ СЛУЧАЕ В ПОЛЕТЕ
}

\author{
Н.В. Касаткин
}

В статье представлены модели совместного принятия решений (CDM) экипажем воздушного судна и руководителем полетов в условиях стохастической неопределенности в виде дерева решений и сети GERT. Приведен пример CDM в особом случае в полете "Отказ левого двигателя (отказ системы регулирования температуры выходящих газов) двухмотоного самолета”. Для комплексного учета факторов, влияюших на процесс CDM в особых случаях в полете, построена интеллектуальная система поддержки CDM, которая позволяет учитывать динамическую, статическую и экспертную информацию о состоянии объекта управления (воздушного судна), внешней среды (характеристики зоны управления воздушным движением и аэродромов) и операторов аэронавигационной системы (характеристики пилота, авиадиспетчера).

Ключевые слова: дерево решений, интеллектуальная система поддержки совместного принятия решений, нарушение взаимодействия, полетная ситуачия, сеть GERT, сценарий развития.

\section{STOCHASTIC MODELING OF THE COLLABORATIVE DECISION MAKING "FLIGHT CREW - AIR TRAFFIC MANAGER" IN FLIGHT EMERGENCY}

M. Kasatkin

Effective interaction "flight crew - air traffic manager" is a prerequisite for ensuring flight safety in standard conditions and during flight emergency. The life of air passengers in the sky and the third parties on the ground depends on adequate interaction between the pilot and the ground services. The airspace users exchange information to achieve the optimal solution agree on the approach and principles of decision-making and apply them in practice. Any incident is the quintessence of errors. The investigation of an aviation incident reveals the mistakes that were made at different stages: pilot training, aircraft maintenance, deficiencies in air navigation services and other points. The main task of this process is to increase the efficiency of the Air Navigation System as a whole, while adhering to the equality of interests of individual participants in air navigation services. In this article the models of the Collaborative Decision Making (CDM) by flight crew and air traffic manager in stochastic uncertainty conditions in the form of a decision tree and a GERT network are presented. The example of CDM in flight emergency "Left engine failure (constraint limit temperature system failure) of two - engine aircraft", is given. For a comprehensive accounting of the factors affecting the CDM process in flight emergency, an adaptive intelligent collaborative decision support system has been built, which makes it possible considering dynamic, static and expert information about the state of the control object (aircraft), the external environment (characteristics of the air traffic control zone and aerodromes) and Air Navigation System's operators (characteristics of the pilot, air traffic controller). The ICDSS analysis allows us to draw conclusions about the need to create databases of two types. The first group includes databases, which are a stationary data source that is created before the start of ICDSS; to the second - a dynamic data source - databases, which are built by the system itself when processing dynamic information about the aircraft, ATC area, ANS operators and further used by it.

Keywords: decision tree, intelligent collaborative decision support system, interoperability, flight situation, GERT network, scenario of development. 